\title{
Introduction to the Fordham University Press Edition
}

\author{
"A credit to the author \\ and an honor to the dead \\ heroes": George \\ Washington Williams's \\ A History of the Negro \\ Troops in the War of the \\ Rebellion, 1861-1865
}

by John David Smith

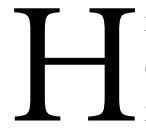

istorians remember George Washington Williams (1849-1891) as an enigmatic nineteenth-century black intellectual who wrote historical nonfiction that underscored African American accomplishment, humanity, manliness, and triumph over slavery and white racism, what Stephen G. Hall describes as a "reflective mediation on the Emancipation in the form of race history." "No other work in our language," T. Thomas Fortune of the New York Globe said of Williams's History of the Negro Race in America from 1619 to 1880, "has proceeded from the pen of a colored author which bears upon its face greater industry, greater love of race, greater learning." Williams amassed his sources "from almost inaccessible quarters" because "written evidence of what we had done in this country was so scarce that to gather it was nothing more nor less than a labor of love." ${ }^{2}$ Fortune dubbed Williams "the Historian of the Race."

Williams's History of the Negro Race in America was the first serious, professional history of American blacks. ${ }^{4}$ Writing in the Magazine of American History, the Reverend Benjamin Franklin De Costa considered the massive, twovolume work "perhaps the most creditable performance that has yet come from the pen of any representative of the African race in America. ${ }^{{ }_{5}}$ Amazingly, as late as 1921 Williams's two-volume work, according to the distinguished black scholar Benjamin Brawley, remained the only authoritative and comprehensive history of African Americans. ${ }^{6}$ In 1887, Williams published a narrower but equally path-breaking work, A History of the Negro Troops in the War of the Rebellion. ${ }^{7}$ The Reverend Joseph E. Joy informed readers of the New Englander and Yale Review that in this book, Williams captured "with wondrous effect" 
the indebtedness that whites had to African Americans for their actions during the Civil War. ${ }^{8}$

Thanks to historian John Hope Franklin's four decades of careful research, scholars now recognize Williams's prominence as nineteenth century America's foremost African American historian. In publishing his History of the Negro Race, Williams "achieved what no other Afro-American had achieved and indeed what no other person had ever achieved. He had provided a sustained, coherent account of the experiences of the Negro people."” By 1887, Franklin explained, Williams "was widely regarded as the historian of his race, for he had written two works that were not only the first of their kind, but compared quite favorably in research and composition with other historical works of the period." 10

But Williams also was complex and complicated-a man with seemingly endless ambition and boundless energy, but who also possessed an immense ego, and who exhibited a consistent pattern of restlessness and self-destruction. Much like William Hannibal Thomas-another northern, freeborn African American soldier, theologian, lawyer, legislator, and author-allegations of personal and professional misconduct, abandoning his wife, and defaulting on debts, hounded Williams after he entered public life. ${ }^{11}$ As early as 1880 , a critic, who earlier had supported his candidacy for a seat in the Ohio legislature, branded Williams "a political trickster ... not fit to be trusted." Franklin's meticulous research proves that throughout his life Williams made "claims for himself that were patently false. In time they would run the gamut from his age to his education to his writings." In Franklin's opinion, Williams had an "almost desperate desire to distinguish himself and to perform an important service for his people." Enormously talented, he also possessed a "flair for calling attention to himself." "It was typical of Williams," Franklin remarks, "to become the center of a heated discussion of desertion, nonsupport, interracial trysts or marriages, or affluence." He was "a flawed but brilliant human being." 12

In his 2005 autobiography, Franklin recalled that despite Williams's penchant for self-promotion and shady behavior, he nonetheless admired and identified with his predecessor. Although possessing little formal education and lacking training as a historian, the pioneer black scholar produced landmark works in American historiography. Franklin credited Williams with inspiring him to write his celebrated textbook From Slavery to Freedom: A History of American Negroes (1947), now in its eighth edition. ${ }^{13}$

The peripatetic George Washington Williams matters to African American history on several levels-as pioneer African American soldier, minister, journalist, lawyer, orator, politician, adventurer, activist, and historian. Williams successfully wove blacks into the fabric of professional historical scholarship. 
He challenged discrimination and overcame white racism by celebrating black accomplishment, racial uplift, and pan-Africanism. These themes ran through his short and enigmatic life like a leitmotif.

Williams descended from free blacks in Bedford Springs, a small community in south-central Pennsylvania. He ran away from home at age fourteen and, using an assumed name, enlisted in the Forty-First U.S. Colored Troops (USCT). He fought in the Virginia campaigns against Confederate forces in September 1864, sustaining multiple battle wounds at Fort Harrison (near Richmond), and observed Petersburg's capitulation in April 1865. Following Appomattox, the War Department dispatched the Forty-First USCT to perform garrison duty on the Texas coast. Upon his discharge from the army in Texas in December 1865, Williams crossed the U.S.-Mexican border to enlist in the revolutionary army that battled Emperor Maximilian. After returning to the United States in August 1867, Williams reenlisted in the army's famed all-black Tenth Cavalry. Williams served in Indian Territory on the western plains until being discharged mysteriously for a non-combat-related gunshot wound in July 1868. According to historian Ira Berlin, by age nineteen, Williams "had seen more army life than the most hardened Civil War veteran." ${ }^{14}$

After leaving his second tour of duty in the army, Williams began an amazing intellectual metamorphosis-from a semiliterate army veteran to a cosmopolitan clergyman. He first studied theology in Missouri, enrolled at Howard University briefly in 1869 , and attended Wayland Seminary in Washington, D.C., in 1870. Later that year, Williams entered Newton Theological Institution in Andover, Massachusetts, where administrators assigned him to the English "remedial" curriculum. Four years later, Williams emerged as the first African American to graduate from the school, a star student who completed the threeyear theology program in two years. In June 1874, clergy in Watertown, Massachusetts, ordained Williams into the Baptist ministry. According to Franklin, Williams "did not learn to write a full, grammatical sentence until he was nineteen and ... never had a course in any kind of history until he went to Andover." 15 A self-made man and a quick study, Williams developed skills as an eloquent speaker, a polished writer, and an urbane clergyman that helped him to grasp opportunities and to move between careers with seeming ease and finesse.

During the 1870s, Williams presented orations that introduced themes that lay at the core of his two books. In "Early Christianity in Africa," his 1874 commencement address at Newton Theological, Williams expressed his early reverence for Africa, his understanding of the tragedies that African Americans endured, and the opportunities they hoped to enjoy. "For nearly three centuries," he explained, "Africa has been robbed of her sable sons. For nearly three 
centuries they have toiled in bondage, unrequited in this youthful republic of the west. They have grown from a small company to be an exceedingly great people-five millions in number no longer chattel, they are human beings; no longer bondsmen, they are free men, with almost every civil disability removed." 16

In a sermon "The Advent of the Colored Soldier," that Williams presented to Boston's all-black Bell Post of the Grand Army of the Republic (GAR), he foreshadowed the central argument of his later book on the USCT, identifying slavery as the cause of the Civil War and celebrating black troops as the lynchpins of the Union's military victory. ${ }^{17}$ Williams maintained that at the "darkest hour of the nation's struggle the negro soldier advanced to the front with firm and steady tread, keeping time to the music of a righteous desire to purchase his own freedom at the cannon's mouth in the battlefront." "Though the hydra of slavery had been slain the evil influences of the institution linger among us," Williams warned. "All we ask now is that we have all the rights that are the reward of those who fought the battles of this country." ${ }^{18}$ Following his ordination in 1874, Williams assumed the pastorate of Boston's historic Twelfth Baptist Church, one of New England's oldest and most prestigious black congregations. He also served as the only African American chaplain of the Massachusetts House of Representatives.

Little more than a year later, however, Williams was on the move, this time to Washington, D.C. Encouraged and backed financially by such influential racial reformers as Frederick Douglass, John Mercer Langston, P. B. S. Pinchback, William Lloyd Garrison, and Wendell Phillips, Williams launched The Commoner, a political newspaper for African Americans that promised to offer "the colored people of the country a guide, teacher, defender, and mirror." 19 Explaining his plan of racial uplift to poet Henry Wadsworth Longfellow, Williams articulated his belief that "the negro ... must come up from his animal nature to live in the higher branches of manhood. This is the plastic period," Williams wrote, "the negro will begin to make history. What manner of history will it be?"20

In The Commoner's first number, published on September 4, 1876, Williams proclaimed his commitment to "Equality of Duties" and "Equality of Rights" and promised to provide "A powerful agent for REORGANIZING THE RACE." ${ }^{21}$ According to Garrison, Williams's new venture would inculcate in the freedpeople "self-respect, self-reliance, active industry, economical thrift, well considered enterprise, mutual co-operation, personal integrity, and exemplary behavior." ${ }^{22}$ Unfortunately, like many post-Civil War newspapers edited by blacks, Williams's weekly publication attracted few subscribers and failed 
after a run of only eight issues. After brief employment with the U.S. Post Office, Williams relocated once again.

This time, Williams moved to Cincinnati, Ohio, in March 1876, assuming the pastorate of another distinguished black congregation, Union Baptist Church. He also began immediately engaging in local Republican politics and delivering impassioned speeches on historical, patriotic, and theological topics. This combination of endeavors enabled Williams to cement ties with white and black Civil War veterans and to establish a political foothold in southern Ohio.

In a July 4, 1876, oration delivered at Avondale, Ohio, Williams traced the history of African Americans in the American republic. Notwithstanding the horrors of slavery, he insisted, black Americans remained steadfast in their loyalty to their adopted land. Williams explained that "when the slave institution was rocking with its living freight; when it had poisoned the life blood of liberty, and seduced the North; when it had precipitated civil war, wasted our army, and emptied our national treasury, and when the life of the our nation hung upon the thread of uncertainty, the slave threw down his hoe, took up his musket, and saved the country." Anticipating twentieth-century scholars who stressed the "agency" of slaves in freeing themselves during the war, Williams insisted that during slavery the black man was "his own deliverer, the defender of the Union. And when the history of this country is written in truth," he predicted, "when Freedom counts her jewels and reviews her glorious army of martyrs - the negro will be there." 23

While in Cincinnati, Williams also returned to newspaper work, contributing weekly columns on education, religion, culture, politics, the military, and race to the Cincinnati Commercial under the nom de plume "Aristides." In keeping with his peripatetic character, however, in December 1877, after less than two years at Union Baptist Church, he resigned his pastorate to pursue politics and law. In October 1877 , Williams ran unsuccessfully as a Republican for a seat representing Hamilton County in Ohio's General Assembly. Although defeated, Williams worked to establish himself as a leader among Cincinnati Republicans. Ambitious and able, he aspired to state, national, and federal office.

Like other black Republicans of his day, Williams denounced former slaveholders then regaining political control in the South, championed the civil rights of the freedpeople, and sought to improve the lives of black northerners who commonly succumbed to the indignities of Jim Crow. Williams strongly championed president Rutherford B. Hayes's southern strategy of empowering the freedpeople by educating them and encouraging blacks to acquire family farms. This required establishing a détente with conservative whites and assuming a gradualist approach to social change. With that end in mind, in 1878, Wil- 
liams wrote Hayes's secretary that he "was the first colored man in the country to give [Hayes's] Southern policy a practical endorsement-and in more than eighty public speeches, urged the people to accept it as the judgment of an honest man, a genuine republican and a noble patriot." ${ }^{24}$

Williams adopted the view of the freedpeople of white liberals like Carl Schurz and Edwin L. Godkin. He defended the former slaves from allegations of inherent inferiority, blaming the condition of servitude for disabling them, arresting their development as a people, and denying them education. Williams considered the ex-slaves victims of slavery, unprepared during Reconstruction for citizenship. In order to advance, blacks first required education, the acquisition of farms, and the establishment of stable families, and then they could set their sights on political rights. African Americans, Williams believed, possessed the innate capacity to participate fully in a Christian democracy and could overcome white racism. But they first required education to acquire the work habits and sense of civic responsibility necessary to engage fully in a democracy.

Like other elite black intellectuals of his day, Williams interpreted African American history as a divine and progressive movement, one that included leaving the South, if necessary. Unlike Frederick Douglass, who opposed the migration of black southerners to Kansas during the 1870s, Williams wrote that "the Exodus was not a political movement. It was not inspired from without. It was but the natural operation of a divine law that moved whole communities of Negroes to turn their faces toward the setting sun." ${ }_{25}$ In 1883 , Williams engaged in vituperative public debate with Douglass over whether or not blacks should remain in the South or migrate to Kansas. ${ }^{26}$ As historian Laurie F. Maffly-Kipp explains, Williams believed that "the divine will was operating through human agency, and blacks would gradually lift themselves up as they learned to turn their religious piety into social action." ${ }^{27}$

In his History of the Negro Race, Williams, according to historian William Toll, used "the historical effects of institutions, especially of slavery," to help blacks understand "the vital relationship between individual rehabilitation and the achievement of full opportunities for the race." ${ }^{28}$ In that work, Williams interpreted slavery as a means of testing, preparing African Americans for a millennial future for themselves-a higher moral message for all African Americans and for the redemption of Africans. "I modestly strive to lift the Negro race to its pedestal in American history," Williams wrote in History of the Negro Race. "I raise this post to indicate the progress of humanity; to instruct the present, to inform the future." ${ }^{29}$ His optimistic, divine-inspired, millennial worldview enabled Williams to interpret slavery, emancipation, and the heroism of the USCT as part of a historical progression inspired by God. "Black millennialism," historian David W. Blight explains, "combined roman- 
ticism about African culture with a Christian, and in some ways distinctively black, view of history itself as a sacred drama. It combined apocalyptic tragedy with the optimism and determinism of the Second Coming of Christ." Both Williams's History of the Negro Race and his A History of the Negro Troops contained what Blight terms "a spiritually reassuring form of memory . . that helped many people cope with despair in the age of Jim Crow." Williams's "histories of African Americans are stories about the fulfillment of an ultimate and sacred American progress." 30

Before publishing his influential histories, Williams sought to uplift his race-and himself-by securing political office or a federal diplomatic appointment. This required legal training. Accordingly, in early 1878 , he began studying law with Judge Alphonso Taft, one of Cincinnati's most acclaimed attorneys and a former member of president Ulysses S. Grant's cabinet. Taft provided Williams an opportunity to study law as well as economic and political patronage. In October 1879, Williams, although not yet admitted to the Ohio bar, but with the imprimatur of powerful Cincinnati Republicans, narrowly won election from Hamilton County to the Ohio House of Representatives, becoming the first African American to sit in that body.

Williams served only one term (1880-81) in Columbus but had a high profile, sitting on numerous committees, introducing many private bills and petitions, and unsuccessfully working to repeal Ohio's ban on interracial marriages. On one occasion, when a Columbus restaurant that catered to legislators denied Williams service because of his race, his colleagues in the General Assembly protested and, according to historian Stephen Middleton, the restaurateur "suffered a temporary financial loss." 31 More controversial was Williams's support of the closing of Cincinnati's Colored Avondale Cemetery, a stance that seriously angered his black constituents. "Williams," Franklin explains, "was more of an integrationist than most of his black constituents, and was not inhibited by the fact that the cemetery that purportedly was a health hazard happened to be black. Many blacks disliked him because they thought him arrogant and conceited or because many whites thought him to be the brightest and the best black citizen in town. Rarely could Williams be called naive, but he was genuinely surprised at being assailed by the Negroes of Cincinnati for introducing the cemetery bill." ${ }^{32}$ With his local support diminished, Williams chose not to run again for office in 1881 and, like his stint as a theologian, his political career ended abruptly. He then decided to get ahead by studying the past.

Williams began considering the writing of history as a serious pursuit as early as 1874 when he published History of the Twelfth Baptist Church, Boston, Mass., from 1840 to 1874 . By 1876, Williams was conducting systematic research 
for his History of the Negro Race. When Williams left office in 1881, he already had decided to write history full time. In 1883, Williams initiated a national campaign to establish an "American Negro Historical Society," one designated to record and preserve "all speeches, orations and books related to the race" as well as all the "files of all the papers conducted by Negroes." 33

Untrained as a historian, and with few African American models to draw upon, Williams nevertheless quickly grasped the importance of accessing and evaluating secondary and primary sources. He traveled to various archives and libraries, conducting primary research at the Library of Congress, the American Antiquarian Society in Worcester, Massachusetts, the Boston Athenaeum, the Massachusetts Historical Society, and the New-York Historical Society, the Lenox and Astor libraries, and the New York Society in New York City. In Cincinnati, Williams relied upon the holdings of the Historical and Philosophical Society and the private library of bibliophile Robert Clark. As a legislator, he had access to the State Library of Ohio and to the history collections of the Columbus Public Library. Throughout his travels, Williams interviewed persons, especially Civil War veterans, black and white, about their experiences.

Although an amateur historian, Williams was methodologically sophisticated for his day, an innovator who gathered his own sources for his writings. He pioneered self-archival work by advertising in southern black newspapers for documentary evidence regarding African American cultural, economic, and social history, and to identify possible interviewees. According to Franklin, Williams "knew that it would not be easy to render a version of history that took into account the role of the inarticulate masses and those whose records could not be found in the usual repositories." Franklin notes that the interviews he conducted "mark Williams as one of the pioneer investigators in the field of oral history." In April 1880, for example, Williams travelled to the western U.S. to conduct oral history interviews of Civil War veterans, including black enlisted men and noncommissioned officers, at military posts in Texas, New Mexico, the Indian Territory, and Kansas. He also conducted extensive research in newspapers before the University of Pennsylvania's engineer-turnedhistorian John Bach McMaster popularized their use in his History of the People of the United States (8 vols., 1888-1913). ${ }^{34}$ Although Williams lacked formal historical training, several prominent white historians mentored him. These included, most prominently, George Bancroft, whom Williams first met in 1881; as well as John Austin Stewart, editor of the Magazine of American History; George H. Moore, author of an influential work on the history of slavery in Massachusetts; and Samuel Austin Allibone, librarian of New York City's Lenox Library. ${ }^{35}$ 
As a historian, Williams insisted on intellectual independence and strove for objectivity. He subjected his sources to critical analysis, identified and corrected the errors of previous writers, and pointed out flaws in historical figures, white and black. He explained to readers of History of the Negro Race that he conducted his research and writing "in the spirit of honest and impartial historical inquiry." 36 Williams, according to Franklin, "was essentially a revisionist" because in his historical writing he addressed subjects heretofore generally ignored, even by blacks, and because Williams integrated African Americans into the narrative of American history-a narrative from which they had been excluded by previous historians. Unlike white writers, Williams accentuated positive aspects of black history, the contributions African Americans had made to American and world history. Williams aspired to the highest standards of historical scholarship, informing his friend U.S. senator George Frisbie Hoar in 1887 that in his historical work, he was committed "to promote science and history." 37

The publication of Williams's History of the Negro Race in 1882 remains a salient moment in African American historiography. Reviewing the book in The Dial, A.L. Chapin complimented the author's ability in

giving interest, clearness and force to his presentation of the subjects treated. The fruit of his labor is a fresh and striking illustration of the capacity of men of this oppressed race for literary work of a high order. The historian appears, indeed, as a champion for the rights and dignity of his people, and hence his testimony is not always unbiased. ... But hitherto almost all that has been written concerning that people is stamped with the prejudices of the dominant white race, and there is need that one should speak plainly and strongly for the other side. The history which contributes most to a correct knowledge of truth is not that which, in scrupulous care for candor and impartiality, grinds off the sharpness of all salient points and so robs facts of their chief interest and meaning, but that in which facts are made to glow from a living soul guiding the recorder's pen. The author's earnest advocacy of a cause which has been so long ignored or belied, is conducted with a temperate, fair-minded spirit, hardly to be looked for and much to be commended.

Chapin predicted that Williams's volumes would inspire blacks to elevate themselves and "correct false views, remove obstacles, and prompt wise measures for developing manhood and maturing the essential qualities of good citizenship in the millions of a race, too long despised and down-trodden." 38 The Atlantic Monthly's reviewer agreed that History of the Negro Race would "be 
a treasury of facts for future students," but pointed out instances where the inexperienced Williams unfairly criticized previous authors, ignored evidence that contradicted his assertions, and lacked an overall "judicial spirit."39

Following publication of History of the Negro Race, Williams concentrated on historical work, researching, writing, and lecturing widely with his characteristic energy and enthusiasm. The onetime semiliterate soldier had emerged as one of the country's foremost African American intellectuals. After hearing Williams speak in Louisville, Kentucky, a journalist reported in 1883 that, "No man of our race with whom we are acquainted possesses his peculiar power in public speaking." ${ }_{40}$ Upon returning to Boston that year, he continued his historical research, began practicing law anew, and sought a diplomatic appointment.

This came to pass in March 1885 when Republican President Chester A. Arthur, then a lame duck, appointed Williams as U.S. minister to Haiti. This was among the most prestigious diplomatic posts reserved for distinguished black men who had served their country. In a curious turn of events, even though the U.S. Senate confirmed his appointment, and after Williams took his oath of service, incoming Democratic President Grover Cleveland (who took office on March 4, 1885) recalled the appointment at Port-au-Prince from Williams before he could occupy it. Williams's posting had become mired in personal and racial politics, and Cleveland named another African American, John E. W. Thompson, to the coveted position instead. The Nation used the episode to condemn what it termed Arthur's "discreditable use of his power" during his last days in office and praised Cleveland's appointment as "a commendable disposition on the part of the Administration to treat the black man exactly like the white man." The magazine then took a gratuitous stab at Williams, noting that his "record showed that he was not fit to represent this Government in a foreign country." 41

Despite unsuccessful appeals to the U.S. Court of Claims to receive his lost salary, Williams looked beyond his failed diplomatic appointment and broadened his horizons overseas. In the years after publishing History of the Negro Race, Williams began working on a book on Reconstruction, one he failed to complete, and lectured widely on African Americans in the Civil War era but also about contemporary Africa, the international slave trade, and colonialism. In 1884, he testified before the U.S. Senate Committee on Foreign Relations urging recognition of the Congo Free State. Four years later, Williams attended the Centenary Conference of Protestant Missions in London and, while overseas, visited Belgium, France, Holland, Germany, and Switzerland. In 1889, as a reporter for Samuel S. McClure's newspaper syndicate, Williams covered an international antislavery conference in Brussels and met Belgian King Leopold 
II. Williams hoped to assist in developing and reforming the Congo by recruiting educated and skilled African Americans, drawing settlers from such industrial schools as Alabama's Tuskegee Institute, to migrate to the Congo. ${ }^{42}$

The following year, without Leopold's blessing but with funding provided by the American railroad magnate Collis P. Huntington (who contemplated investing in Africa), Williams conducted a fifty-three-day trip from Liverpool to Boma, Congo Free State, determined to examine the condition of laborers in the colony then owned and ruled by Leopold. Reflecting on his trip, Williams wrote that he had "encountered many dangers, confronted death on several occasions, have hungered and thirsted and passed through experiences enough to fill a volume." He added that while returning to Angola from East Central Africa, he traveled through "a district disturbed by war where it was impossible to get food; and I learned that the supreme virtue of endurance, acquired during my military service, was demanded in the full." ${ }^{43}$

Williams's famous report An Open Letter to His Serene Majesty, Leopold II, King of the Belgians and Sovereign of the Independent State of Congo (July 1890), one of three that he published on conditions he observed in the Congo, exposed the Belgians' brutal and inhumane exploitation of the native Africans. Williams held Leopold responsible for the violence his agents inflicted on the Congolese and for brutalizing and degrading them. "Your Majesty's Government," Williams wrote, "has sequestered their [the Congolese] land, burned their towns, stolen their property, enslaved their women and children, and committed other crimes too numerous to mention in detail. It is natural that they shrink from 'the fostering care' your majesty's Government so eagerly proffers them." ${ }_{44}$

Williams's Open Letter served as a primer, an inspiration for later critics of Belgian rule in the Congo specifically and of European colonialism generally. Widely reprinted, it publicized the deleterious impact that Europeans had on Africans. As Franklin noted, prior to publishing An Open Letter, Williams had prepared a report on the dire conditions for Africans in the Congo for President Benjamin Harrison. Franklin praised Williams's "courage" in publishing his eloquent condemnation of Leopold because it resulted in denunciations of him in Belgium and attracted little notice in the U.S. Certainly An Open Letter had a negative impact on his relationship with Huntington, who had hoped to expand business ties in the Congo. ${ }^{45}$ "A closer scrutiny of conditions in the Congo would come only after such 'credible' persons as Roger Casement of the British foreign office and Mark Twain made charges against Leopold," Franklin explained in $2008 .{ }^{46}$

Following his tour of the Congo, in January 1891 Williams lectured in Cairo, Egypt, and in June 1891 he moved to England, intending to write a book on the Belgians' policies in the Congo. In ill health following his African trip, he died 
in Blackpool, England, in August 1891. Williams's obituary in the New-York Tribune remarked that he was the first African American to serve in the Ohio legislature and observed matter-of-factly that his History of the Negro Race "added much to his reputation." ${ }^{47}$

Williams's personal experiences with army life in the USCT, in Mexico, and in the Indian Territory perhaps explain his special interest in military history. His belief that Africans and later African Americans were especially able soldiers appeared throughout History of the Negro Race. Williams devoted parts of thirteen chapters to military history in that two-volume work. This focus emerged full-blown in 1887 in his A History of the Negro Troops. According to Franklin, Williams believed that "It was in the crucible of war . . . that a people showed whether or not they deserved the favors of and protection of the government under which they lived. In this nation's civil conflict Williams was certain that his people had won the right to full citizenship." 48 When residing in Cincinnati, the Ohio Encampment of the GAR appointed Williams judge advocate, with the rank of colonel, and he remained deeply interested in black veterans' affairs. ${ }^{49}$ He bore the honorary rank with pride and used the title "colonel" publicly and on his publications. Believing that Americans undervalued the role of the USCT in squashing the slaveholders' rebellion, in the late $188 \mathrm{os}$, Williams drew up a detailed plan for and led an unsuccessful national campaign, including testifying before the Senate Library Committee, to erect a monument to black Civil War soldiers and sailors near Howard University. ${ }^{50}$

By the 1880s, only one book, The Negro in the American Rebellion: His Heroism and His Fidelity (1867), by the ex-slave William Wells Brown, had appeared. Whites generally ignored the topic but blacks, especially USCT veterans like Williams, had a seemingly insatiable appetite to learn about blacks' roles in destroying slavery and their contribution to the war that preserved the Union. Williams would become the champion, the chronicler of the USCT.

Franklin explains that the mid-188os was a fortuitous time for a study of the USCT and that Williams, who had been interested in the subject since his student days at Newton Theological, was perhaps the most qualified person in America to undertake it. Williams brought impressive credentials to the task, including his personal experience as a USCT veteran. He already had devoted 190 pages to the subject in his History of the Negro Race. ${ }^{51}$ The availability of new primary sources, especially the Official Records of the War of the Rebellion (the first volumes of which appeared in 1880), helped make Williams's book authoritative, "scientific." Franklin notes correctly that Williams must have been among the first writers to rely upon the Official Records, sources that today remain central to any serious Civil War historian's research. ${ }^{52}$ To supplement these records, Williams conducted additional research in Boston's State House, 
in the departments of State and War and the Library of Congress in Washington, in various state adjutant-generals' papers, and in orderly books of officers who had commanded USCT regiments. Williams also examined printed government records, such as the Congressional Globe and the Congressional Record (which began publication in 1873) and, as in his History of the Negro Race, he mined newspapers and interviewed persons central to his story, especially whites who had commanded black troops.

As a former member of the USCT, Williams wrestled with the "objectivity" question when writing A History of the Negro Troops. In the book's preface he addressed the challenge of writing what later generations of historians would term "contemporary history." The "writing of events within living memory," Williams explained, "requires both fortitude and skill to resist the insidious influence of interested friends and actors, to separate error from truth with an even and steady hand." Acknowledging that he had fought in many of the battles that he described, Williams remarked that he "relied very little on personal knowledge, preferring always to follow the official record." This would prevent him from succumbing to "partisan feeling" and allow him to "maintain a spirit of judicial candor" (xxxvii). ${ }^{53}$

Notwithstanding Williams's commitment to objectivity, his A History of the Negro Troops falls clearly into what David W. Blight has termed the "emancipationist vision" of the Civil War's meaning, one that privileged the war's impact on race and black freedom over sectional reconciliation and the celebration of common American characteristics. This interpretation appeared "embodied in African Americans' complex remembrance of their own freedom, in the politics of radical Reconstruction, and in conceptions of the war as the reinvention of the republic and the liberation of blacks to citizenship and Constitutional equality." ${ }^{54}$ In Williams's case, he dedicated his book "To the Negro Soldiers, who Heroically Served their Country in the War of the Rebellion this Record of their Valor is Inscribed by Their Comrade in Arms."

Williams's history of the USCT, according to historian Donald R. Shaffer, constituted his contribution to "the battle for memory" then raging between northerners and southerners and whites and blacks. Like Williams, a leader among black GAR members, other blacks shared their experiences as men of the USCT. "For years an active member of the Grand Army of the Republic," Williams explained in A History of the Negro Troops, "I have heard with deep interest, at camp-fires and encampments, many narratives of the heroic conduct of Negro soldiers, but my enthusiasm has never led me away from the record" (xxxvii). Williams and other black veterans sought to remind the nation of their contributions to the war effort, believing that knowledge of their military valor might counter the deteriorating place of black southerners 
following the overthrow of Reconstruction. "Not surprisingly," Shaffer observes, "Williams spent much of this book substantiating the worth of black soldiers to the Union cause and their valor in battle. With the activities of black soldiers often ignored or belittled in many general war histories written by white authors, he had little choice." 55

Shaffer correctly notes that Williams framed his book around several essential questions that remained unanswered, at least for whites, in the $1880 \mathrm{os}$. Had African Americans been good soldiers? Had they fought bravely? How did they compare with white troops? Williams spent much of the book's 350 pages answering these questions-decidedly in the affirmative. Williams used A History of the Negro Troops to argue that the nearly 180,00o blacks who donned the Union blue possessed the qualities of exemplary soldiers. They were men, fully the equal of whites. In his book, Williams felt compelled to document the bravery and manhood of African American soldiers-traits whites assumed inherent in their own race but generally found wanting in blacks. ${ }^{56}$ According to Williams, no longer could anyone doubt the USCT's military record. It had become "not only the proud and priceless heritage of a race, but the glory of a nation" (xl). Prior to publication of A History of the Negro Troops, an African American newspaper announced Williams's book, hoping that it would "have a wide circulation, especially among our own people, and then, perhaps, we would discover the Negro has not been such a coward as his enemies would have us believe." 57

In 1887, when Harper and Brothers published Williams's A History of the Negro Troops, African American readers already considered him the historian of their race. Some referred to Williams as "the Negro Bancroft," comparing him favorably to America's grand narrative historian George Bancroft, the author of the multivolume History of the United States from the Discovery of the American Continent (10 vols., 1850-74). The Washington Bee, a leading African American newspaper that had greeted Williams's History of the Negro Race harshly in 1883, applauded A History of the Negro Troops in December 1887, deeming it "a credit to the author and an honor to the dead heroes."

Reviewing their historical record as soldiers in world history, Williams argued that Negroes enjoyed a long record of success as combat soldiers. $\mathrm{He}$ credited Egyptian King Pepi of Egypt's Sixth dynasty as the first to utilize black soldiers after invading and conquering the territory of Negro tribes to the south. In Egypt, Williams explained, soldiers comprised a highly respected class, just below priests, and the Egyptian army had rigid requirements for entering military service. Negroes met those strict requirements. He pointed out that while the Egyptians typically enslaved conquered peoples, they chose instead to recruit defeated Negro tribes into their army rather than to relegate 
them to slave labor. Williams detailed that black soldiers in ancient Egypt proved their worth by achieving victories in five major battles where "the country was distant and the marching difficult" (4). Overall, he identified "an unbroken chain of historical evidence of the military employment of Negroes" throughout antiquity (6).

Williams devoted considerable attention to the use of Negro soldiers in the American and French Revolutions. Both the British and the American colonists vied for the services of free blacks and slaves as troops, Williams wrote. Even though the British promised to emancipate slaves who joined their army, he believed that most slaves were naturally inclined to join the colonists in their fight for freedom from English rule. When the colonists realized the benefits of employing free blacks and slaves as soldiers, Williams noted proudly, "everywhere they won the confidence and applause of their white compatriots; and they did their duty so naturally and faithfully that their color was lost sight of" (21). Williams asserted that Negroes proved essential to the colonists' cause, participating in virtually every major battle. "Their splendid feats of valor covered their dark visage as with a halo of glory" (22).

Their success as soldiers during the American Revolution notwithstanding, Williams believed that black military service in revolutionary-era Haiti exemplified best the Negro's military valor. He described with admiration how the Haitians founded a successful Negro republic after hard-fought military victories against the Spanish, French, and English. Williams held the Haitian General Toussaint L'Ouverture in the highest regard, describing him not merely as a great military leader, but as a person who carried himself with humility and set rancor aside, a characteristic that Williams later attributed to black troops in the American Civil War. At one pivotal moment in battle, Williams wrote, L'Ouverture rallied his soldiers, formerly slaves but now freemen, against the battle-tested French veterans. "New life flowed through the Negro columns," Williams wrote, "like a gift from the gods. Toussaint's voice was as new wine to their fainting hearts, and his inspiring presence was now their glorious ensign of battle" (35). Williams complimented the overall military prowess of the humble Haitians against the haughty French. "The pets of the Imperial household never encountered fiercer fighting," he remarked (34).

Throughout A History of the Negro Troops, Williams equated freedom with progress and slavery with retrogression. The "peculiar institution," he explained, was a cancer, a root evil, that ate away at the American republic. It threatened America's ship of state "like a dangerous coast with hidden reefs, where wild gales and stormy breakers blow and dash. It overshadowed every other question of national importance, and against its hidden reefs and treacherous currents the fierce gales of public events seemed driving the Ship of State" 
(40). By 1860, slavery and white southerners' determination to reopen the African slave trade led to the breakup of the Union. "Negro slavery was the evil genius that was rending the Republic" (44).

Williams lamented that early in the Civil War president Abraham Lincoln hesitated to mobilize black soldiers, determined to save the Union with or without slavery. As a result, during the first two years of the conflict, he instructed field commanders to return escaped slaves to their masters. Like Lincoln, most northerners considered blacks unqualified to serve as soldiers. Slavery, they believed, had rendered African Americans abnormally "pliable, docile, and submissive" (45). Williams noted ironically that the Confederates, intimately familiar with slavery and persons of color, moved first to recruit black soldiers, organizing a few regiments of free blacks for garrison duty. Their contribution to the South's war effort, however, proved to be negligible. By war's end, however, when the U.S. Army already had mustered in almost 180,00o black soldiers, the Confederates elected, in a last gasp measure, to recruit slave soldiers. "The Negro," Williams quipped, "who had been manifestly and confessedly the cause of the war, was now the hope of both Union and Confederate governments" (210).

The string of Union military defeats in 1862, Williams explained, ultimately forced Lincoln to realize that his policy of conciliation and non-interference with slavery had failed. His Final Emancipation Proclamation of January 1, 1863, gave the president a double-edged sword to "deplete the labor force of the enemy and to put the American uniform upon the Negro" (72). Williams emphasized that when the U.S. government finally recruited and mobilized them, blacks rushed to the colors because they realized that "it was now seen to be a war about them, and was gradually becoming a war for them" (97-98). In New York, for example, 2,300 of the state's 9,000 Negroes eagerly enlisted within sixty days, overcoming the state governor's initial objections to their recruitment.

Despite the blacks' zeal to join the Union ranks and to fight the southern oligarchy, most white northerners considered Negroes servile by nature and doubted their ability to fight. In return for their help in saving the republic, African Americans received only "cold, silent doubt," Williams remarked (122). "So when the exigencies of a great civil war seemed to call the Negro from obscurity and the dark places assigned him by race prejudice, he was confronted by intense malevolence" (122). Notwithstanding the antipathy directed at them by whites, black soldiers remained patient, anxiously awaiting their chance to demonstrate their mettle under fire. "No one welcomed it more sincerely than the Negro himself, and history shall record his splendid bearing, his heroic deeds, his proud achievements" (127). 
Williams devoted five of the sixteen chapters in A History of the Negro Troops to describing the blacks' combat experiences. He arranged his military accounts geographically (by military department) and then chronologically. From Virginia to Texas, from Tennessee to Louisiana, and from late 1862 to mid-1865, Williams wrote, the black troops fought valiantly and exhibited tremendous courage, despite frequent "fateful fortuitous circumstance" that led them into many fierce and bloody battles in 1863 and 1864 (120).

The valiant assault by the Fifty-Fourth Massachusetts regiment on Fort Wagner, South Carolina, in July 1863 provided an early test of the Negroes' courage. "From a purely military stand-point," Williams explained, "the assault upon Fort Wagner was a failure, but it furnished the severest test of Negro valor and soldiership. It was a mournful satisfaction to the advocates of Negro soldiers to point the doubting, sneering, stay-at-home Negro-haters to the murderous trenches of Wagner. The Negro soldier had seen his red-letter day, and his title to patriotic courage was written in his own blood" (141). Similarly, the February 1864 battle of Olustee, Florida, according to Williams was "recklessly fought" and doomed from the start (145). Nonetheless, Williams wrote, the men of the USCT who served in the Department of the South exhibited "steadiness and courage." For them "there were no trials too severe, no duties too arduous, no death too bitter" (151).

Williams's narratives of the service of the USCT in the Mississippi Valley, with the Army of the Potomac, with the Army of the Cumberland, and with the Army of the James reached the same conclusion. At Port Hudson, Louisiana (May-July 1863), wave after wave of black troops endured heavy losses and conducted themselves with élan. In battle "the Negro himself, with the confidence of a child just learning to walk, was now conscious of his power, and was anxious to consecrate it with lavish generosity to the Government with whose uniform and flag he had been intrusted" (157). At Milliken's Bend (June 1863), black troops engaged in hand-to-hand combat with Rebel forces in some of the fiercest fighting of the war. According to Williams, the Negro troops engaged at Milliken's Bend refused to quit and "covered themselves with glory" (159). He considered "the unimpeachable valor of the Negro troops . . a a priceless heritage of the race for whose freedom they nobly contended" (161). In Virginia-at Fort Powhatan (May 1864), Petersburg (July 1864), Deep Bottom (August 1864), and Fort Harrison (September 1864) —and in Tennessee-at Nashville (December 1864) — the black troops carried out their martial duties, in Williams's estimation, "with valor and prowess" (179).

Although Williams couched his narratives of black participation in the war in millennial terms-describing the black military experience as "the romance of North American history"- - he nevertheless underscored the inhuman treat- 
ment and discrimination Negro troops regularly experienced (xl). Most egregious, Williams complained, was the refusal of the Confederates to accord the USCT prisoner-of-war status, enslaving, torturing, imprisoning, or murdering the blacks instead of respecting them as soldiers and allowing them to surrender. Williams was one of the first African Americans to describe in detail the infamous massacre of between 250 and 300 black soldiers at Fort Pillow, Tennessee, on April 12, 1864. ${ }^{59}$ This episode, he concluded, "outraged every sentiment of humanity, and dishonored the uniform of Lee and Jackson, the Christian soldiers of the Confederacy. As long as brave deeds blaze in the firmament of national glory, as long as patriotism is revered and valor honored, so long will the gallant defence of Fort Pillow by the Negro Spartans be held in sacred remembrance by the loyal friends of a ransomed and reunited nation" (195).

Black troops also faced discrimination closer to home-from northerners who opposed their service and held them responsible for the war-and from federal officials who treated them as less than equal to white soldiers. Williams described in detail the bloody July 1863 antidraft riots in New York City, where mobs of working class whites vented their anger and resentment at helpless black men, women, and children and prevented the Fifty-Fourth Massachusetts regiment from passing through the city en route to the South. In addition to what Williams termed the "Negro-haters who violently opposed the military employment of Negroes," African American troops also had to contend with receiving unequal pay (122). Whereas white recruits received $\$ 13$ per month, $\$ 3$ of which constituted a clothing allowance, black recruits received $\$ 10$ per month with $\$ 3$ withheld by the government for clothing, a policy that Williams condemned as "unwise and unjust" (106). Not until June 1864 did the federal government remedy this gross injustice.

In addition to inferior pay, the men of the USCT received more than their fair share of fatigue and garrison duty. The black troops commonly believed that white soldiers, including high-ranking officers, considered them brothers in arms while others treated them as personal servants. Drawing upon his own experience in the army, Williams said that fatigue duty "is trying and tempting to the best troops, and it is not infrequently positively demoralizing" (117). He argued that the black soldiers "had enlisted to fight, not to be hewers of wood. They were proud of their uniform, and desired above all things to be led against their ancient and inveterate foes. It was natural, therefore, that they should feel disappointed, and in some instances doubt the Government that had broken faith with them" (196).

Contemporary reviewers greeted A History of the Negro Troops enthusiastically but not uncritically. The New York Sun complimented Williams for filling 
missing chapters in the history of Negro soldiers from antiquity to modern times, in the history of American blacks generally, and in the military history of the Civil War particularly. After praising the breath of the research materials Williams culled, the reviewer declared that the sources "have been verified and sifted with an amount of care and candor that reflect high credit on the author, and the resultant facts are grouped, projected, and interpreted with a truly noteworthy degree of literary skill." While the Sun's critic identified minor omissions in Williams's narrative of black soldiers in the Haitian Revolution, he wrote that when evaluated by any standard, Williams "has demonstrated at one stroke that the negro race possess not only the gifts of a soldier, but those of a judicial expounder of events, and of an accomplished man of letters." The reviewer agreed with Williams that the mobilizing of almost 180,0oo black soldiers for Lincoln's army was unparalleled in world history, and their heroism warranted the erection of a monument to their memory. ${ }^{60}$

In its review of A History of the Negro Troops, The Dial considered it "gratifying to find a negro entitling his record of his race's brave deed." The reviewer judged A History of the Negro Troops an important contribution to the expanding historical literature on the Civil War, "full of absorbing interest, and . . . told in a graphic and finished style." The book proved, "for those who still need it, that the negro wants but the proper recognition to take his place as a man and a citizen." The magazine's reviewer found most appealing Williams's narration of the slaves' wartime evolution from "contraband" to freeman-what modern scholars term "the emancipation process" - but faulted the author's "natural impatience with the dilatory steps toward the enfranchisement of his race." Williams, the reviewer argued, undervalued the obstacles President Lincoln, the U.S. Congress, and the U.S. Army juggled in balancing constitutional restraints and overturning the rebellion. "The wonder is, not that emancipation came so late, but that it came so soon as the second year of the war." 61

The Literary World praised Williams's A History of the Negro Troops as a substantial work of military history but also from what its reviewer patronizingly termed "the humanitarian standpoint" because its author was "of African blood." The writer congratulated Williams for his book's "intelligence, discretion, and excellent workmanship," qualities that made it "a credit to him, to his race, and to their part in the war which ushered in emancipation." The reviewer nevertheless then added condescendingly: "Considering our common impressions of the racial source of it, it is remarkably well written. The tendency to 'fine writing,' which might have been expected, is slight, scarcely noticeable, in fact; the style is manly, modest, strong; the book presents the facts, and presents them in an orderly, dignified, and impressive form." ${ }^{62}$ 
The Nation criticized Williams's A History of the Negro Troops (along with Joseph T. Wilson's The Black Phalanx: A History of the Negro Soldiers of the United States) for falling short of writing a definitive history of the USCT, noting that his failure to master the sources left the reader "with a renewed interest in the subject, but with a very imperfect sense of clear comprehension." The reviewer pointed out errors in Williams's text, criticizing the "disproportionate amount of space [given] to the early days of recruiting, and to the services of the first regiments organized." That said, the Nation's critic admitted that "the record of the colored troops, if painted in rather too glowing colors by . . . historians of their own race, is nevertheless a solid and honorable one." 63

The Boston Post gave Williams's book the most complete and overwhelmingly negative review, noting positively that "it can be said in praise of his work that he has an easy and excellent style, rarely marred by attempts at fine writing; that he has collected much interesting material; that his book will be entertaining to civilians not already conversant with the subject, and that it will have absorbing interest for readers of his own race." Having admitted this, the reviewer continued to fault Williams's treatment of black soldiers in ancient Egypt as erratic, sketchy, and weakened by digressions. The writer considered Williams's account of the enrollment and mobilization of troops in the northern states unfortunately "shiftless and incomplete." He also charged that Williams included "much matter in the text which might better be assigned to an appendix," while leaving many questions unasked and hence unanswered. By failing to tabulate the losses of black troops in action, Williams missed a chance to underscore "the solemn roll of martial martyrdom which invites the respect and compels the admiration of even the most prejudiced negro-hater!" 64

The Post's reviewer also noted that while Williams wrote about the major battles that featured black troops, he chided him for omitting detailed narratives of the more than one hundred actions in which the USCT participated in during the war's final two years. "Testing the author's thoroughness by the experiences of the colored regiments from our own state, we find Fort Wagner well described ... Olustee very confusedly and unsatisfactorily sketched, Honey Hill misrepresented, and no allusion whatever made to the charge and capture of a battery on James Island by the Fifty-Fifth Massachusetts." 65

Concluding his review, the Post's critic pronounced Williams's book "disappointing" military history. He admitted that while Williams "evidently read and investigated widely ... he apparently lacks the experience or the faculty which leads a historian, when his first researches are over, to arrange, to assimilate, to fill gaps by further research, and to patiently work up his materials until he can present an orderly, coherent and complete narrative." Overall, the Post considered Williams's A History of the Negro Troops unsatisfying. It left "abun- 
dant room" for more careful and thorough analysis. The subject cried out "for a real 'History' of the creation of a well-equipped and well drilled army from a mob of emancipated slaves; as important an event in military annals as in the development of the race in whose education and enfranchisement it was a principal factor." 66

Dudley Taylor Cornish, the first modern historian of the USCT, also gave Williams's A History of the Negro Troops a mixed review. Writing in 1956, Cornish noted that Williams's book far surpassed the two other contemporary books on the subject: William Wells Brown's The Negro in the American Rebellion: His Heroism and His Fidelity (1867) and Wilson's The Black Phalanx: A History of the Negro Soldiers of the United States in the Wars of 1775-1812, 1861'65, like Williams's A History of the Negro Troops, also published in 1887. The three men shared important characteristics. They were African Americans, had participated one way or another in the struggle against slavery and postwar white racism, and lacked formal training as historians. ${ }^{67}$ In Cornish's opinion, the work of all three writers suffered from weak organization, poor documentation, lack of objectivity, and a tendency toward excessively praising the black troops and unfairly condemning their critics and opponents. Cornish admitted, however, that "It is perhaps too much to expect men who had themselves experienced the trials of Negro soldiers to use balanced judgment in the discussion of a subject which for them was either all right or all wrong with no gradations between." 68

Of the three pioneer works, Cornish nonetheless considered Williams's book the most scholarly in tone, most thoroughly researched and detailed, and best documented. That said, Cornish wrote that "in spite of his obvious ability and intelligence," Williams's "story of the evolution of Union Negro soldier policy is far from clear. . . . It is rich in battlefield anecdote and color, enlivened by reports from sometimes unidentified participants, but even more than Brown's book it is overwritten to the point of tediousness. Williams weakened his work by continually overstating the case for the Negro soldier; he tried too urgently to show that every Negro was a gallant hero." Despite the deficiencies in Williams's A History of the Negro Troops, Cornish noted that until the publication of his own book, The Sable Arm, in 1956, it remained the standard work. ${ }^{69}$ Eleven years later, Cornish again judged Williams's book the best of the early studies of black military service in the Civil War, yet again faulted it as "anecdotal, detailed, heavy with official reports and correspondence, but overwritten to a point of tediousness." 70

When evaluated by twentieth- and twenty-first-century scholarly standards, not surprisingly, Williams's A History of the Negro Troops easily warrants Cornish's criticisms, and more. Williams championed the military service of the 
USCT uncritically. So strong was his need to compensate for the devaluation of blacks in Jim Crow America that he overstated their accomplishments in the Civil War. His narrative offered little introspection or nuance. He subjected African American troops to virtually no criticism, admitted few flaws in their actions, and recognized no missteps or divisions within their ranks. In his obsession to celebrate the black troops' "valor," Williams looked past their prejudices, their conflicts with each other, and their deficiencies as soldiers and men. Filiopietistic and defensive, Williams strained his own credibility by transforming the Negro soldier into an unreal heroic figure, so magnanimous that following Appomattox he reportedly forgave his former enemies, embraced "the murderers of his kinsmen under the pretext of law" (229).

Modern readers unquestionably will consider A History of the Negro Troops poorly documented, excessively florid in style, and riddled with long extracts in the Victorian literary mode. It is hyperbolic, exaggerated, and biased toward blacks. In one instance, Williams characterized Negro soldiers as "modest, patient, heroic, and efficient from the gray dawn of the struggle until the bright noontide of victory. Their sufferings, sacrifices, and triumphs are now the priceless heritage of a grateful nation" (22). In the end, Williams's flowery prose, excessive generalizations, and overstatements undermine the efforts of one who claimed to have written "in the interest of history and science" (xxxix).

Williams fell short of interpreting contemporary history satisfactorily. As a Civil War veteran, he was too close to his subject, writing just twenty-two years following his own military service and Confederate defeat at Appomattox. Williams failed to attain the "objectivity" he sought to achieve. He proved incapable of concealing his feelings regarding the condescending treatment black troops received from white enlisted men and officers and, especially, the atrocities and incidents of cruel treatment against blacks by Confederates at Fort Pillow and elsewhere. "The ghastly horrors of Fort Pillow," Williams had admitted in History of the Negro Race, "stand alone in the wide field of war cruelties." Writing about such events tested the historian. "The affair demands great fortitude in the historian who would truthfully give a narrative of such bloody, sickening detail," Williams explained. ${ }^{11}$

On a more positive note, however, Williams's A History of the Negro Troops was an original work that remains important both as an example of early African American historiography, a work of racial romanticism, and as a pioneering book that underscored black agency and determination. "Looking back over the centuries," Williams concluded in A History of the Negro Troops, "there would be little else to record of the poor, patient Negro save his sufferings and degradation were it not for the luminous flashes of his martial glory, which cast a light upon the background of an otherwise sombre picture" (238). Beyond a 
doubt, Williams insisted that military service showcased the Negro's "martial valor." In doing so, the Negro "disappointed his enemies and surprised his friends" (230). Unquestionably, Williams's work foreshadowed recent scholarship by Christopher Leslie Brown, Philip D. Morgan, and Peter Blanchard, students of slave armies in world and comparative societies. ${ }^{72}$ Williams had a firm understanding of slavery's repressive grip on blacks and anticipated later scholars who elucidated the slaves' resilience and their determination to overthrow their chains. Slavery had reduced the bondsmen and women to automatons. "They were callosed $[s i c]$ and hardened by cruel blows and barbarous treatment. But they were not dead; they needed only the salve of human sympathy and kindness to call them into action" (46). In detailing the USCT's military campaigns, Williams also prefigured historian Noah Andre Trudeau's Like Men of War: Black Troops in the Civil War, 1862-1865 (1998). More than a century earlier, Williams had hammered home the argument that during the Civil War, African Americans were not passive; they fought hard and died for their freedom.

It is important to contextualize Williams's work. He wrote A History of the Negro Troops at the moment that proscription, de facto segregation, and informal and formalized racial violence were enveloping African American southerners. Nine years later, the Plessy v. Ferguson case (1896) codified the separate but equal doctrine as the law of the land. As historian Joseph T. Glatthaar has explained, Williams had a deep personal interest in using his history to defend black troops from white prejudice and condescension. He wrote as much to chronicle the black past as to establish his patriotism and that of his fellow black veterans. ${ }^{73}$ Writers before him had ignored or paid lip service to the USCT. Williams considered it vital to tell the black troops' side of the story and, not surprisingly, he overstated it.

Williams employed what Donald R. Shaffer refers to as "the language of manliness" to legitimize the men of the USCT. Shaffer identifies a degree of "defensiveness about black men as men" as well as soldiers on the part of Williams and other early black chroniclers of the African American Civil War experience. ${ }^{74}$ Early black intellectuals responded to the white racism of their day in various ways, but most commonly by overstating black accomplishment and achievement in exaggerated and racially romanticized ways. In Williams's case, he answered the tendency of whites to belittle black soldiers in the war and to slight them as veterans by glamorizing the black troops' accomplishments and overstating their "valor." Williams's dream of a national monument to black Civil War soldiers and sailors did not come to pass for more than a century, reaching fruition finally in 1998. It stands today near the U Street-Cardozo stop on the Green Line of the Washington, D.C., Metrorail system. 
Although Williams overstated the role that black troops played in saving the Union, especially their heroic acts, A History of the Negro Troops remains an important classic text. It provides a window to the uses of history in the postemancipation decades and a reminder of the blacks' contributions at a critical moment in their nation's history. In A History of the Negro Troops, Williams, who historian Benjamin Quarles described as "the Negro soldier-historian," offered an authentic voice of a participant, one who had fought shoulder to shoulder with the USCT and who could tell their story. ${ }^{75}$ Like them, he had experienced white racism and, in the moment of battle, the rush of overthrowing slavery and proving African American manhood. It required no hyperbole by Williams to attest to the black troops' important contributions to the Union cause. They helped emancipate their black brethren with the bayonet and became symbols of accomplishment, freedom, and hope in the age of Jim Crow.

\section{Acknowledgments}

I thank Paul A. Cimbala, editor of the series The North's Civil War, for asking me to undertake this edition, and Fred Nachbaur, Fordham University Press director, for his interest in my work and his seemingly endless patience. Eric Newman, the managing editor of the Press, assisted me in the last stretch; Teresa Artman copy edited the manuscript.

My research assistants Lisa F. Andrusyszyn and James J. Harris provided immensely valuable support in preparing my introduction, as did student assistants Jon Helmandollar and Chris Ruehlen. Colleagues Shawn Alexander, Ira Dworkin, and Lea Fridman made valuable suggestions regarding collateral source materials. Professor Fridman also invited me to participate in a workshop on Williams at the Benjamin N. Cardozo School of Law, Yeshiva University, in 2009. Librarians Elizabeth B. Dunn and Karen Jean Hunt at Duke University, Sebastian Hierl of Harvard University, and Joseph Jackson at the Library of Congress, facilitated my access of obscure George Washington Williams texts. Lois Stickell and Ann Davis and her colleagues in the Interlibrary Loan Department, J. Murrey Atkins Library, The University of North Carolina at Charlotte, expertly tracked down additional scarce research items for my use. So too did Charles Bittner of The Nation.

Unfortunately, two friends, Walter B. Hill and John Hope Franklin, did not live to see the publication of this edition of Williams's A History of the Negro Troops. Walter took special interest in my work over several decades and provided unequaled access to the treasures of the National Archives. He invited me 
to serve on the Historian Advisory Committee, African American Civil War Memorial Foundation, Washington, D.C. John Hope played no small part in the conception of this edition. His encouragement, friendship, and immense corpus of scholarship continue to inspire me.

\section{Notes}

1. Stephen G. Hall, A Faithful Account of the Race: African American Historical Writing in Nineteenth-Century America (Chapel Hill: University of North Carolina Press, 2009), 7, 160, 180.

2. ["Geo. Washington Williams"], New York Globe, March 17, 1883.

3. "The Historian of the Race," New York Globe, May 19, 1883.

4. George Washington Williams, History of the Negro Race in America from 1619 to 1880, Negroes as Slaves, as Soldiers, and as Citizens, 2 vols. (New York: G. P. Putnam's Sons, 1882). A second printing appeared in 1883 and a two-volume-in-one edition appeared in 1885 .

5. Benjamin Franklin De Costa, review of George Washington Williams, History of the Negro Race in America from 1619 to 1880, in Magazine of American History 9 (April 1883): 299.

6. Benjamin Brawley, A Social History of the American Negro, Being a History of the Negro Problem in the United States Including a History and Study of the Republic of Liberia (1921; reprint ed., New York: Macmillan, 1970), xxiii.

7. George Washington Williams, A History of the Negro Troops in the War of the Rebellion, 1861-1865, Preceded by a Review of the Military Services of Negroes in Ancient and Modern Times (New York: Harper \& Brothers, 1887). A second printing appeared in 1888 .

8. Joseph E. Roy, "Our Indebtedness to the Negroes for Their Conduct during the War," New Englander and Yale Review 15 (November 1889): 353.

9. John Hope Franklin, George Washington Williams: A Biography (Chicago: University of Chicago Press, 1985), 115.

10. John Hope Franklin, "Williams, George Washington," in Rayford W. Logan and Michael R. Winston, eds., Dictionary of American Negro Biography (New York: Norton, 1982), 658.

11. On Thomas, see John David Smith, Black Judas: William Hannibal Thomas and "The American Negro" (Athens: University of Georgia Press, 2000).

12. Franklin, George Washington Williams, 90, 40, 34, 40, 179, 241.

13. John Hope Franklin, Mirror to America: The Autobiography of John Hope Franklin (New York: Farrar, Straus and Giroux, 2005), 125, 310.

14. Ira Berlin, "Soldier, Scholar, Statesman, Trickster," New York Times Book Review, November 17, 1985, p. 12.

15. Franklin, Mirror to America, 125.

16. George Washington Williams, "Early Christianity in Africa" (1874), quoted in Franklin, George Washington Williams, 10-11.

17. On the Bell Post, see Barbara Gannon, The Won Cause: Black and White Comradeship in the Grand Army of the Republic (Chapel Hill: University of North Carolina Press, 2011), 23.

18. George Washington Williams, The Advent of the Colored Soldier: Memorial Sermon Delivered before the Robert A. Bell Post 134, G.A.R., Sunday, May 24, 1874 (Boston: James H. Earle, 1874), 6, 12, 14 (italics in original).

19. Franklin, George Washington Williams, 26. 
20. George Washington Williams to Henry Wadsworth Longfellow, July 24, 1875, quoted in William Toll, "Free Men, Freedmen, and Race: Black Social Theory in the Gilded Age," Journal of Southern History 44 (November 1978): 580.

21. The Commoner, September 4, 1875, masthead.

22. William Lloyd Garrison to George Washington Williams, July 19, 1875, in The Letters of William Lloyd Garrison, ed. Walter M. Merrill and Louis Ruchames, 6 vols. (Cambridge, MA: Belknap Press of Harvard University Press, 1981), 6:384.

23. George Washington Williams, Centennial: The American Negro from 1776 to 1876. Oration delivered July 4, 1876, at Avondale, Ohio (Cincinnati: Robert Clarke \& Company, 1876), 24-25.

24. George Washington Williams to B. K. Rogers, December 5, 1878, quoted in James M. McPherson, The Abolitionist Legacy: From Reconstruction to the NAACP (Princeton: Princeton University Press, 1975), 93-94.

25. Williams, History of the Negro Race, 2:534.

26. George W. Williams, "The Historian of the Race: Replies to Hon. Fred'k Douglass," New York Globe, May 19, 1883.

27. Laurie F. Maffly-Kipp, "Redeeming Southern Memory: The Negro Race History, 1874-1915," in W. Fitzhugh Brundage, ed., Where These Memories Grow: History, Memory, and Southern Identity (Chapel Hill: University of North Carolina Press, 2000), 174.

28. Toll, "Free Men, Freedmen, and Race," 581, 582.

29. Williams, History of the Negro Race, 2:iv.

30. David W. Blight, Race and Reunion: The Civil War in American Memory (Cambridge, MA: Harvard University Press, 2001), 321-22.

31. Stephen Middleton, The Black Laws: Race and the Legal Process in Early Ohio (Athens: Ohio University Press, 2005), 254-55.

32. Franklin, George Washington Williams, 93.

33. George Washington Williams, "Col. Williams Proposes a 'Negro Historical Society,'” New York Globe, June 16, 1883.

34. Franklin, George Washington Williams, 103-5.

35. On Moore's importance and influence on Williams, see John David Smith, "George H. Moore: 'Tormentor of Massachusetts,'” in Randall M. Miller and John R. McKivigan, eds., The Moment of Decision: Biographical Essays on American Character and Regional Identity (Westport, CT: Greenwood Press, 1994), 211-226.

36. Williams, History of the Negro Race, 2:iii.

37. Franklin, George Washington Williams, 107, 113, 125, 108.

38. A. L. Chapin, review of George Washington Williams, History of the Negro Race, from 1619 to 1880 , in The Dial 3 (March 1883): 252-53.

39. Anonymous review of George Washington Williams, History of the Negro Race, from 1619 to 1880, in Atlantic Monthly 51 (April 1883): 564-69.

40. Cleveland Gazette, October 6, 1883, quoted in Franklin, George Washington Williams, 140.

41. "The Week," The Nation 40 (May 14, 1885): 392.

42. "To Go to Africa," Cleveland Gazette, March 8, 1890. On Williams's plans for uplifting the Congolese, see Ira Dworkin, "American Hearts: African American Writing on the Congo, 1890-1915" (Ph.D. diss., City University of New York, 2003), 40; Jeanette Eileen Jones, In Search of Brightest Africa: Reimagining the Dark Continent in American Culture, 1884-1936 (Athens: University of Georgia Press, 2010), 63; and Stanford M. Lyman, Militarism, Imperialism, and Racial Accommodation: An Analysis and Interpretation of the Early Writings of Robert E. Park (Fayetteville: University of Arkansas Press, 1992), 47-54.

43. George Washington Williams to Robert H. Terrell, October 14, 1890, Robert H. Terrell Papers, Manuscript Division, Library of Congress, Washington, D.C. 
44. An Open Letter to His Serene Majesty, Leopold II, King of the Belgians and Sovereign of the Independent State of Congo, by Colonel the Honorable Geo. W. Williams of the United States of America (1890), reprinted in Franklin, George Washington Williams, Appendix 1, p. 246 (italics in original). Also see Adam Hochschild, King Leopold's Ghost: A Story of Greed, Terror and Heroism in Colonial Africa (Boston: Houghton Mifflin Company, 1998), 112.

45. Franklin, George Washington Williams, 220.

46. John Hope Franklin, "Williams, George Washington," in Henry Louis Gates Jr. and Evelyn Brooks Higginbotham, eds., African American National Biography, 8 vols. (New York: Oxford University Press, 2008), 8:322-23.

47. Obituary, "George W. Williams," New-York Tribune, August 5, 1891.

48. Franklin, George Washington Williams, 110.

49. Gannon, The Won Cause, 18. Williams served in this capacity for one year.

50. Franklin, George Washington Williams, 171, 174.

51. See History of the Negro Race, 2:228-418.

52. Franklin, George Washington Williams, 127.

53. All references to Williams's A History of the Negro Troops in this introduction are parenthetical and refer to the Fordham University Press edition.

54. Blight, Race and Reunion, 2, 198.

55. Donald R. Shaffer, After the Glory: The Struggles of Black Civil War Veterans (Lawrence: University Press of Kansas, 2004), 180-81.

56. Ibid., 182.

57. "New Book on the Negro and the Rebellion," Cleveland Gazette, December 11, 1886.

58. "The Negro Soldiers," Washington Bee, December 10, 1887.

59. On the disputed number of deaths at Fort Pillow, see John Cimprich and Robert C. Mainfort Jr., "The Fort Pillow Massacre: A Statistical Note," Journal of American History 76 (December 1989): 830-37.

60. Anonymous, "How the Negroes Fought," New York Sun [November 16, 1887?], clipping in John Hope Franklin Papers, Rare Book, Manuscript, and Special Collections Library, Duke University (hereafter cited as Franklin Papers, Duke). Franklin cites this review as appearing on November 16, 1887, but the review did not appear on that date.

61. Anonymous review of George Washington Williams, A History of the Negro Troops in the War of the Rebellion, in The Dial 8 (February 1888): 252.

62. Anonymous review of George Washington Williams, A History of the Negro Troops in the War of the Rebellion, in Literary World 19 (February 18, 1888): 55.

63. "Histories of the Colored Troops," The Nation 46 (March 1, 1888): 180-81.

64. "Review of 'Negro Troops in the Rebellion,'” Boston Post, November 21, 1887, clipping in Franklin Papers, Duke.

65. Ibid.

66. Ibid.

67. On Brown and his book, see John David Smith, "Introduction," in William Wells Brown, The Negro in the American Rebellion: His Heroism and His Fidelity (1867; reprint ed., Athens: Ohio University Press, 2003), xv-xli. On Wilson and his book, see Dudley Taylor Cornish, "Foreword to the Da Capo Edition," in Joseph T. Wilson, The Black Phalanx: African American Soldiers in the War of Independence, the War of 1812, \& the Civil War (1887; reprint ed., New York: Da Capo Press, 1994), [i-ix].

68. Dudley Taylor Cornish, The Sable Arm: Negro Troops in the Union Army, 18611865 (1956; reprint ed., New York: Norton, 1966), 317.

69. Ibid., 317-18.

70. Dudley T. Cornish, “The Negro," in Allan Nevins, James I. Robertson Jr., Bell I. Wiley, eds., Civil War Books: A Critical Bibliography, 2 vols. (Baton Rouge: Louisiana State University Press, 1967), 1:216. 
71. Williams, History of the Negro Race, 2:359.

72. See Christopher Leslie Brown and Philip D. Morgan, eds., Arming Slaves From Classical Times to the Modern Age (New Haven: Yale University Press, 2006), and Peter Blanchard, Under the Flags of Freedom: Slave Soldiers \& the Wars of Independence in Spanish South America (Pittsburgh: University of Pittsburgh Press, 2008).

73. Joseph T. Glatthaar, Forged in Battle: The Civil War Alliance of Black Soldiers and White Officers (New York: Free Press, 1989), 257.

74. Shaffer, After the Glory, 184.

75. Benjamin Quarles, The Negro in the Civil War (1953; reprint ed., Boston: Little, Brown, 1963), 95. 